\title{
Néhány gondolat a szimbolikus rendszerek szerepéről az építészetben és általában a környezetalakítás kultúrájában
}

\author{
HOZZÁSZÓLÁS PIERRE LÉVY „AZ ÉRTELMISÉG ÚJ FELELŐSSÉGE \\ A KOMMUNIKÁCIÓ KORÁBAN” CÍMUU ÍRÁSÁHOZ
}

$\mathbf{N}$

$\mathbf{F}$

0

$\mathbf{R}$

Szerzői információ:

Ders Cisaba

Építész 2003-ban szerezte diplomáját a PTE PMMF múszaki karán, azóta a doktori iskola hallgatója. A 2006/2007 tanévben Fulbright-ösztöndíjas vendégkutató volt a Columbia egyetem várostervezési karán, jelenleg a londoni Univeristy College-ban folytat városfejlesztési és tervezési tanulmányokat. Kutatásaiban és írásaiban az építészet szemszögéból, de a lehetố legtágabb perspektívában szemléli a világot. Fố kérdései, amelyeknek a megválaszolására törekszik: Mit tudunk ma a világról? Mi köze van ennek az építészethez?

E-mail: csabaders@yahoo.com

$\mathbf{M}$

Á

C

I

Ó

$\mathbf{S}$

$\mathbf{T}$

Á

$\mathbf{R}$

S

$\mathbf{A}$

Így hivatkozzon erre a cikkre:

D

Csaba Ders. „Néhány gondolat a szimbolikus rendszerek szerepéről az építészetben és általában

a környezetalakítás kultúrájában”.

A

Információs Társadalom VIII, 4. szám (2008): 24-28.

$=$ https://dx.doi.org/10.22503/inftars.VIII.2008.4.6 $\rightleftharpoons$

A folyóiratban közölt müvek

a Creative Commons Nevezd meg! - Ne add el! - Így add tovább! 4.0

Nemzetközi Licenc feltételeinek megfelelöen használhatók. 
Csaba Ders

\section{Néhány gondolat a szimbolikus rendszerek szerepéról \\ az építészetben és általában a környezetalakítás kultúrájában}

\section{Miért éppen építészet?}

Az építészet a legáltalánosabb értelemben olyan tudomány és múvészet, amely az emberi szellem és a fizikai valóság között teremt kapcsolatot valamilyen algoritmus segítségével. Ez a kapcsolat - természetéból fakadóan - szükségképpen szimbolikus. Az építészet emberi és társadalmi motivációi és azok az ismeretek, amelyeket ezek érdekében mobilizál az emberi tudás és kultúra szinte teljes spektrumát felölelik, vagyis az építészet valamiféle gyújtópontba sưríti a Lévy által említett „kollektív intelligenciát”, ezért ideális terep lehet a cikkben megfogalmazott szimbolikus rendszerek átjárhatóságának vizsgálatához.

\section{Hadd szemléltessem ez† néhány történelmi példával!}

Az egyik legközismertebb talán a Parthenon, amelynek a létrehozásában az építész mellett az összes szabad múvészet képviselói is aktívan részt vettek. Nem meglepó tehát, hogy az épület tömegének megformálásából, a szinte észrevétlen, de tudatos torzulásokból kirajzolódnak a kor geometriai és perspektivikus alapismeretei és egész térszemlélete. ${ }^{1}$ Idóben és térben hozzánk közelebbi példákkal szolgál a gótika, amelyben a technika és a múvészet legfrissebb vívmányai - a vázas építészeti megoldások vagy az ólomüveg ablakok - egy asszociációs láncolaton keresztül finom szcenikai eszközrendszerré állnak össze, melynek segítségével maga a stílus a kor egyházi világképét képes máig meggyőző érzékletességgel megjeleníteni.

A leglátványosabb példák talán a 20. század elején az egész világon végigsöprô múvészetelméleti fejlődés eredményei. Moholy-Nagy vagy Kepes munkája nyomán ugyanis - hogy csak néhány világhírú magyar nevét említsem - olyan új látásmód születik, „a látás új nyelve”, ${ }^{2}$ amely a Bauhaus iskoláján keresztül az építészeti térben is nagyszerúen kifejeződik.

Az építészet tehát - úgy tûnik - a tudományok és a múvészetek világképében megfogalmazott struktúrákat szintetizálja és interpolálja a fizikai környezet dimenziójába. Egy olyan intermedier, amely egyrészt szellemi tartalmakat tömörít fizikai környezetté, másrészt a felhasználói oldalon ezeket a tartalmakat teszi mindenki számára hozzáférhetôvé.

\footnotetext{
${ }^{1}$ Aldo Rossi: Esszék az épitészetröl. Az Akropolisz.

${ }^{2}$ György Kepes 1944. Language of Vision.
} 


\section{Az építészeti tér és térképzet} tölteni?

Mi is az a médium, melynek segítségével az építészet képes ezt a szerepét be-

A kérdés megválaszolását egy hétköznapi példával kezdeném. Életem egyik meghatározó élménye volt, amikor jó pár éve, már felnôtt fejjel, idősebb Nóránt Laci bácsival a sellyei erdókbe mentünk kirándulni. Az akkor már nyugdíjas kertészmérnök - lépten-nyomon lehajolva, megcirógatva egy-egy számomra közömbös növényt - percekig mesélt. Az addig fứ-fa-virág-bokor felbontású (4 bit mélységú) érzékelő/értelmező rendszerem a többórás séta folyamán elképesztő fejlődésen ment keresztül. Az a közeg, amely városi emberként leginkább a csendjével, harmonikus színkészletével, vagyis visszafogottságával túnt fel, egy szemvillanás alatt izgalmas ingerközeggé változott. A Laci bácsi által átadott információértelmezố képesség ugyanis az addig passzívan visszaverôdő ingereket értelmes, befogadható struktúrába kezdte rendezni.

Az építészeti tér értelmezése során is hasonló ismeretekhez nyúlunk vissza, például a rajzórán elsajátított szín- és kompozíciós szabályokra támaszkodunk vagy geometriai alapelemekre lebontva, illetve azokból építkezve értelmezzük az összetett formákat. A valóságban az adott befogadó az említett ismeretkombináción túl szinte a teljes ismeretanyagát ${ }^{3}$ mobilizálja a beérkező ingerhalmaz lehetséges értelmezéséhez szükséges adattömörítési eljárások végrehajtásához. Ez az értelmezési folyamat az, melynek során a tér komplex ingerei a felhasználóban koherens térképzetté állnak össze.

Ezek az ismeretek természetesen nemcsak a befogadás, hanem a tervezés folyamatát is alapjaiban határozzák meg. Ugyanis az adott struktúra értelmezése gyakorlatilag a létrehozásának az inverze, a közvetítớ közeg pedig nem más, mint az ebból a kommunikációból kialakuló szimbólumrendszer, vagyis az építészeti nyelv.

Az építészek a tér megfogalmazása során tehát erre a legtágabb értelemben vett kultúrára támaszkodnak, amelynek a zavarai a szimbolikus rendszer zavarain keresztül az építészeti tér múködésének az anomáliáiban is szükségszerúen manifesztálódnak.

\section{Az építészeti szimbólumrendszer fejlődése}

Le Corbusier ${ }^{4}$ volt az a nagyhatású látnok, aki a 20. század elején végbement markáns átalakulási folyamatokat képes volt egységes, új városépítészeti vízióban összefoglalni. Ố volt az, aki felismerte, hogy a motorizáción, a mindennapokba beszivárgó technológiai forradalmon, az egyre fokozódó urbanizáción, az új társadalmi eszményképeken vagy az új múvészeti látásmódon keresztül kibontakozó civilizációnak új térkultúrával kell magát kifejeznie. A kor szellemét összegzố szimbólumrendszerével olyan víziót fogalmazott meg, amelyre megdöbbentốen fogékonynak bizonyult a világ,

\footnotetext{
${ }^{3}$ Cornelis van de Ven 1987. Space in Architecture.

${ }^{4}$ Le Corbusier 1925. The City of Tomorrow.
} 
és ez a „modern” látásmód az 1939-es New York-i világkiállításra már kész városfejlesztési rendszerré fejlődött. ${ }^{5}$

Le Corbusier-nek sok szempontból igaza volt, a 60-as évekre azonban elég tapasztalat gyúlt össze ahhoz, hogy meginduljon egy erjedési folyamat, ami ennek a világképnek a helytállóságát egyre több szempontból megkérdőjelezte.

1960-ban megjelent könyvében Kevin Lynch ${ }^{6}$ például a felhasználó oldaláról, empirikus úton kezdte vizsgálni az úgynevezett „modern” városi környezet múködését. Nem tett mást, mint ellenôrizte ennek a szimbólumrendszernek az olvashatóságát, rádöbbentve az építészeket arra, hogy nem sokat tud az általa létrehozott „termékek” használóiról. Lynch eredményei alapján világosan kiderült, hogy a felhasználók teljesen más környezetkulturális alapokon tájékozódnak, mint amire a „modern” térkoncepció épül.

1961-ben Jane Jacobs ${ }^{7}$ eleve megkérdőjelezte a felülról lefelé építkező koncepciók alkalmazhatóságát, és a város múködésének bizonyos ökológiai felfogásával, a helyi közösségek bonyolult önszervezốdési mechanizmusainak a perspektívájából bizonyította a „modern” szemlélet univerzálisnak tartott doktrínáinak a helytelenségét, vagyis tulajdonképpen igazolta azt, hogy a „modern” felfogás szimbólumrendszerével megrajzolt város nem múködik.

Ez a két gondolatmenet jól illusztrálja a továbblépés fő irányát is, amely talán úgy foglalható össze, hogy az építészeti szimbólumrendszer tartalmi deficitben van: egyrészt rosszul ragadja meg saját korának ismereteit, másrészt képtelen közvetíteni azokat.

Az építészetelméleti kutatások ezért egyrészt nyitni kezdtek az építészet közegét meghatározó diszciplínák felé, másrészt olyan új szimbólumrendszerek kidolgozásába fogtak, amelyek a „modern” koncepciók jellemzően múvészetelméleti összefüggésekre épülö építészeti nyelve helyett az „alapszavak” szintjén képesek megragadni ezt az „új komplexitást”.

Ezek között talán az egyik legkiemelkedóbb példa a space syntax ${ }^{9}$ Bill Hillier nevéhez fúződő elmélete, amely egy új szociomorfológiai elemkészlet segítségével épített hidat az építészet és a szociológia tudományterületei közé.

Ez a szemléleti nyitás kibớvítette az építészet határait a társdiszciplínák értelmezési tartományára, bevezetve az épitett környezet jóval inkluzívabb logikai konstrukcióját. A másik fontos jelenség az építészet és a többi designmúfaj fokozatos feloldódása a kibôvült értelmezési tartományhoz igazított fizikai környezettervezés jóval általánosabb müfajában.

5 „A 20. század valódi poétái azok a tervezók, építészek és mérnökök, akikben feldereng egy látomás, megalkotnak egy csodálatos víziót, és képesek ezt a való világ törvényeire lefordítani az emberek boldogságára" Official Guide to the 1939 World's Fair, 29.

„A történet, amit mi itt clmesélünk, és ami a világ minden tájáról New Yorkba vonzza az embereket, tulajdonképpen nem más, mint ez a megtervezett környezet és megtervezett ipar, vagyis ez a megtervezett társadalom" Lewis Mumford 1939. The World of Tomorrow: Science, Culture and Community at the New York World's Fair:

${ }^{6}$ Kevin Lynch 1960. The Image of the City.

${ }^{7}$ Jane Jacobs 1961. The Death and Life of Great American Cities.

${ }^{8}$ Ders Csaba 2008. Egy áj komplexitús felé. Építészfórum http://epiteszforum.hu/node/8426

${ }^{9}$ http://www.spacesyntax.org 


\section{Kibertér, virtuális valóság vagy a fizikai valóságot behálózó és kiegészítő információs technológia?}

Az építészeti térképzet kapcsán eddig szisztematikusan a fizikai környezetról beszéltem. Az információs kor esetében azonban olyan elementáris változással állunk szemben, ami ismét küldetésük újragondolására készteti az építészeket, megkérdôjelezve a „fizikai környezet” fogalmának relevanciáját. Ahhoz, hogy ebben a kérdésben eligazodjunk, először meg kell értenünk ezeknek az új technológiáknak a térhez való viszonyát.

Az információs technológia fejlődésével egyre égetốbbé vált a kérdés, hogy a kialakuló és egyre komplexebbé váló „információs térnek” mi a viszonya a „valósághoz”. Ahogy a városépítészetben Le Corbusier, úgy a technológiai jövóképben William Gibson science fiction író alkotta meg azt a fogalmat, amely mintegy másfél évtizedig meghatározta a gondolkodásunkban ezt a viszonyt. A kibertér (cyberspace) ${ }^{10}$ szó a közhasználatban megragadt értelmezés szerint ,a valóság felett lebegô” közös szellemi tér, afféle „társas hallucináció” önálló identitással, nem kizárva azt a lehetôséget sem, hogy adott esetben csak ebben a térben létezó jelenségekról, a fizikai tértól független identitáshoz kötődő létezésról beszéljünk. A definícióban rejlő implicit tartalom a mi szempontunkból azonban az, hogy ez tulajdonképpen egy önálló kultúra és egy sajátos, független szimbolikus rendszer feltételezését jelenti.

Fontos felismernünk a párhuzamot a steril technokulturális logikai konstrukció, Le Corbusier univerzálisnak szánt utópiája és a Lévy által említett, minden ismeretet szinkronizálni képes új szimbolikus rendszer között. Vegyük észre a mind a három esetben fennálló kulturális feszültséget az univerzálisnak szánt kormányzó gondolat és az egyedi közösségek belsố kulturális rendszere között! ${ }^{11}$

Nem véletlen, hogy az új információs térnek az ezredforduló táján körvonalazódó paradigmáját a „mindenütt jelenlevőség” (ubiquity) attribútuma révén állítják szembe a kibertér utópikus koncepciójával. ${ }^{12}$ Az új térkoncepció ugyanis nem autonóm jelenségként fogalmazza meg többé az információs teret, hanem a fizikai környezetet kiegészítố és így az emberi környezetkultúrába illeszkedő komplex térként.

Ez az újabb paradigmaváltás tovább tágítja az építészet értelmezési tartományát: az építészeti tér és az épített környezet fogalma után az érzéki (érzékelhetô) tér koncepciója válik a kor ismereteit összegezni képes logikai konstrukcióvá. Az érzéki tér fogalma egyrészt új dimenziót definiál a környezetalakítás szimbólumrendszerének, másrészt bevonja a tervezés folyamatába az emberi szubjektumot vizsgáló tudományokat is, az interakció-dizájn ${ }^{13}$ új gyújtoófogalmába rendezve.

${ }^{10}$ William Gibson 1984. Neuromancer.

"Ennek lényegét az MIT Oxygen projekrje kapcsán Stephen H. Wildstorm foglalja össze a Business Week 2000. július 17-ei számában megjelent Can Oxygen Turn Sci-fi into Reality? címú cikkében: „Ahelyett, hogy az embereknek kellene megtanulniuk használni a számítógépet, a számítógépnek kellene megtanulnia, hogy együttmúködjön az emberekkel."

${ }_{12}^{2}$ http://www.acm.org/ubiquity/about.html

${ }^{13}$ Paul Dourish 2004. Where the Action is: The Foundations of Embodied Interaction. 
E két fejlődési trend megragadásával szerintem jól látszik a Lévy által szorgalmazott közös szimbólumrendszer felé vezetô - nem egyenes, de annál határozottabb - út. Úgy tû́nik, hogy az építészet folyamatosan táguló értelmezési tartománnyal és egyre kifinomultabb szókészlettel tart egy összegzô szimbólumrendszer irányába.

\section{Konklúzió}

Számomra ez a szellemi kaland több felismeréssel szolgált:

- Lévy perspektívájából kibomlott egy alternatív (talán koherens) építészettörténeti narratíva.

- A szimbólumrendszerek jelentôségének tisztázásával pontosabban azonosíthatóvá válik az a folyamat, ahogy az építészet más tudományokkal kommunikál, illetve számukra is mérhető, vizsgálható dimenziót teremt.

- Az építészeti szimbólumrendszerek fejlődésének számbavétele talán hozzájárulhat egy általánosítható kép kialakításához a szóban forgó jelenségekról. 